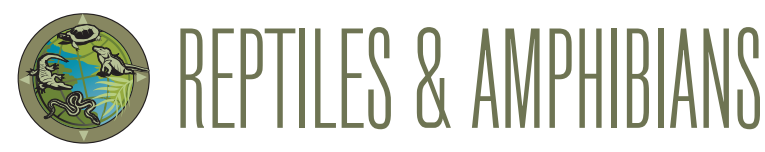

\title{
New Records of the Bicolored Frog, Clinotarsus curtipes (Jerdon 1853) (Amphibia: Anura: Ranidae), from the Northern Western Ghats, India
}

\author{
Omkar V. Yadav ${ }^{1}$, Amrut R. Bhosale², and Sujith V. Gopalan ${ }^{3}$ \\ ${ }^{1}$ Department of Zoology, Amdar Shashikant Shinde Mahavidyalaya, Medha, Satara, Maharashtra, India (sarpaveda@gmail.com) \\ ${ }^{2}$ Department of Zoology, Sadguru Gadage Maharaj College, Karad, Maharashtra, India (amrutb18@gmail.com) \\ ${ }^{3}$ Department of Zoology, University College, Trivandrum. Research Centre, University of Kerala, Thiruvananthapuram, Kerala, India \\ (sujith.vg@gmail.com [corresponding author])
}

$\mathrm{T}$ he Bicolored Frog (Clinotarsus curtipes) is endemic to the Western Ghats of India, where it occurs in a variety of forest types from Kerala in the south northward to the southern edge of western Maharashtra (Biju et al. 2004; Frost 2021) (Fig. 1). Juveniles and adults are strictly terrestrial in forested areas except during the breeding season, when adults move to perennial ponds and streams (Daniels 2002). Tadpoles aggregate in schools (Krishna and Krishna 2005), emerge from water at metamorphosis, and move into the forest in large groups (Wemmer and Nanjappa 1996).

During herpetological expeditions in the northern Western Ghats, we encountered three populations of Bicolored Frogs in southern Maharashtra from March 2007 to May 2019 (red dots in Fig. 1). One was at Zolambi, Sangli District $\left(17.1604861^{\circ} \mathrm{N}, 73.8613499^{\circ} \mathrm{E}\right.$; elev. $621 \mathrm{~m}$ asl $)$ and two, at Waki $\left(16.2913305^{\circ} \mathrm{N}, 74.011127^{\circ} \mathrm{E}\right.$; elev. 648 $\mathrm{m}$ asl) and Rajapur $\left(16.3236416^{\circ} \mathrm{N}, 74.0160916^{\circ} \mathrm{E}\right.$; elev. $648 \mathrm{~m}$ asl), were in Kolhapur District. Two specimens were collected at Rajapur. These individuals were photographed in the field prior to capture (Fig. 2A-B) and then euthanized with MS222. Liver tissue was collected and preserved in absolute ethanol and subsequently stored at $-20^{\circ} \mathrm{C}$ for DNA analysis. Specimens were fixed in 10\% formalin, preserved in $70 \%$ ethanol, and deposited in the Museum and Research Collection Facility at the National Centre for Biological Sciences, Bengaluru, Karnataka (NCBS-AQ-223-4). A photographic voucher of an adult male from Zolambi was deposited in the Zoological Reference Collection in the Lee Kong Chian Natural History Museum, National University of Singapore (ZRC (IMG) 1.160).

DNA extraction, PCR amplification of mitochondrial $16 \mathrm{~S}$ rRNA, and sequencing followed Gopalan et al.

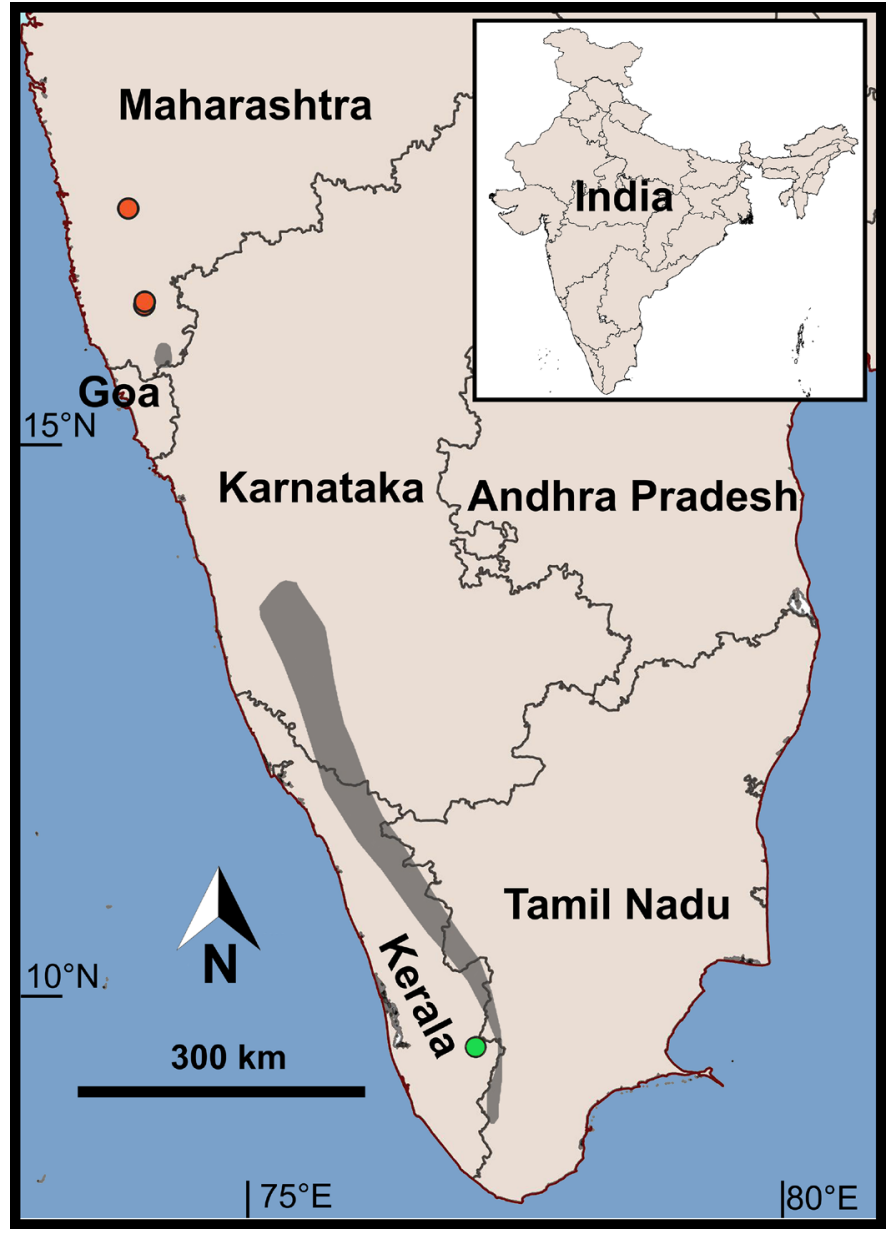

Fig. 1. Map showing the known distribution of the Bicolored Frog (Clinotarsus curtipes) in the Western Ghats, India. Previously documented areas (Biju et al. 2004) are marked in gray. The new localities in Sangli and Kolhapur Districts of Maharashtra are indicated by red dots and a locality in Kumily, Idukki District, Kerala, near the southernmost extent of the species range is marked by a green dot. 

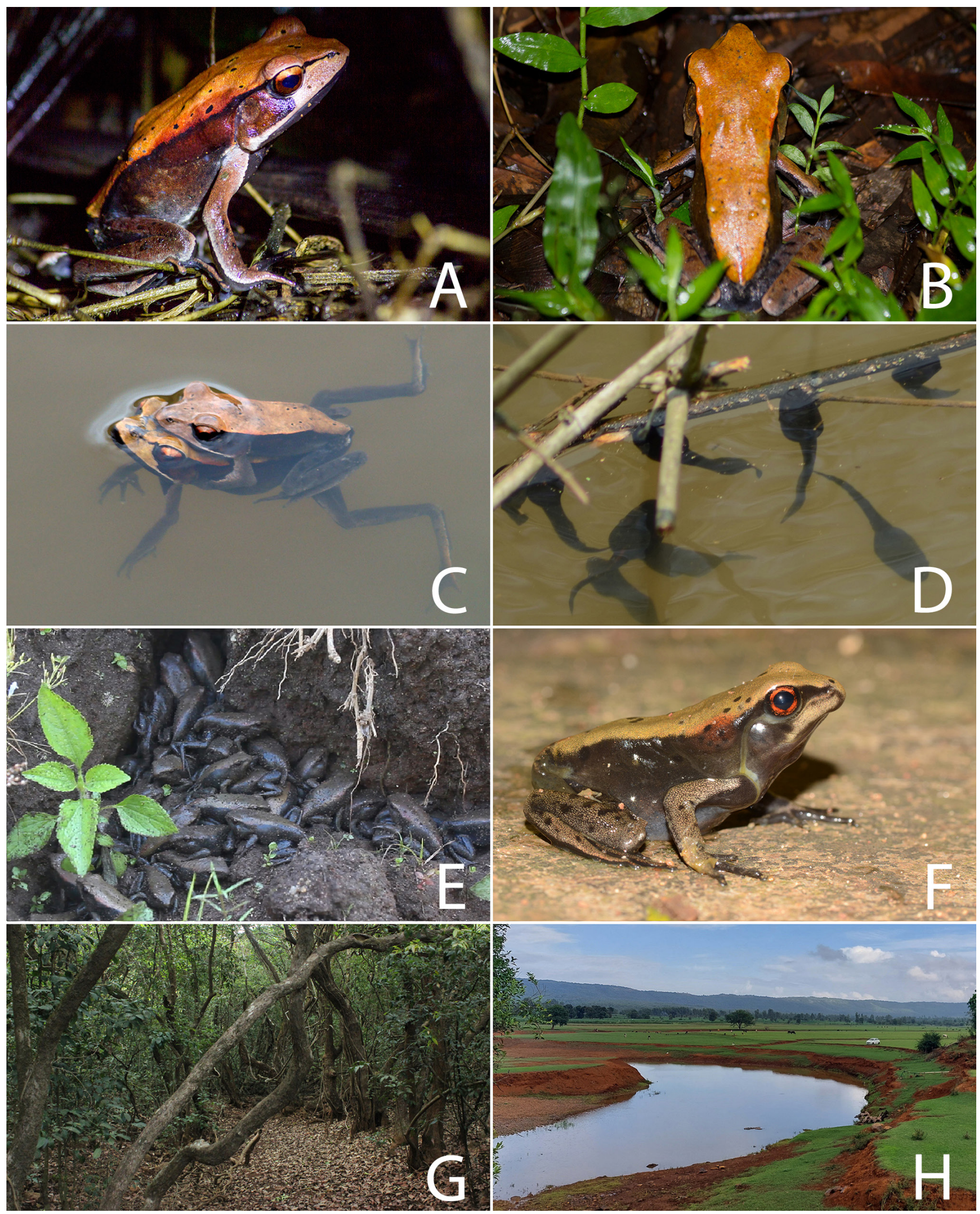

Fig. 2. Bicolored Frogs (Clinotarsus curtipes) from Rajapur, Kolhapur District, Maharashtra: An adult male (A-B), a pair in amplexus (C), larvae (D), recently emerged froglets (E), a juvenile (F), adult habitat in the Wakeshwar Sacred Grove (G), and a breeding site (H). Photographs by Sujith V. Gopalan (A-F) and Omkar V. Yadav (G-H). 
(2014). We used reference sequences of $16 \mathrm{~S}$ rRNA from Clinotarsus curtipes (KM069013.1), C. alticola (KR869787.1, KR869788.1), and C. penelope (MG909603.1) available in GenBank with the sequences generated in the present study to construct a phylogenetic tree with a sequence from a Fungoid Frog (Hydrophylax malabaricus) (KP826817.1) as an outgroup. The Maximum Likelihood (ML) Tree was constructed using MEGA ver. 5 (Tamura et al. 2011) with T92+G as the nucleotide substitution model. The branch support was evaluated using 1,000 bootstrap replicates (Felsenstein 1985). The pair-wise genetic distances between the species were calculated using the Kimura 2-parameter method in MEGA ver. 5 (Tamura et al. 2011). The new sequences have been deposited in GenBank under accession numbers MZ358102-4.

The sequence of $16 \mathrm{~S}$ rRNA generated in this study clustered with the reference sequence of Clinotarsus curtipes obtained from Genbank with high bootstrap value (Fig. 3). Since color, pattern, and morphometrics conformed to previously published descriptions (e.g., Daniels 2002) and the sequences showed a high degree of homology ( $>99 \%$; Table 1 ) with the reference sequence of $C$. curtipes, we confirmed the identity of the species as $C$. curtipes.
We found terrestrial adults (Fig. 2A-B) to be solitary in forested areas (Fig. 2G) except during the breeding season (Fig. 2C), which begins in early June and ends by September. We found eggs in large ponds (Fig. $2 \mathrm{H}$ ) and lakes from late June to September. Tadpoles aggregate in large numbers (Fig. 2D) from September through March, metamorphs emerge en masse (Fig. 2E) by May, and juveniles (Fig. 2F) move into the forest.

The new records extend the range of the species approximately $150 \mathrm{~km}$ north of the closest known record in extreme southern Maharashtra (Fig. 1). Habitat use and reproduction

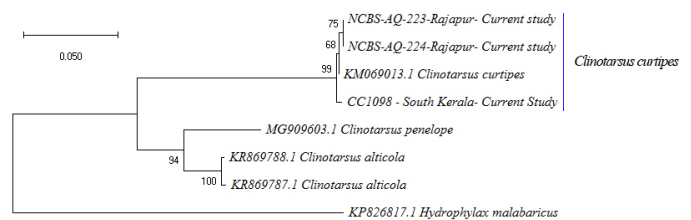

Fig. 3. Phylogenetic tree (ML) based on $16 \mathrm{~S}$ rRNA sequences of Bicolored Frogs (Clinotarsus curtipes) generated in the present study, reference sequences from Genbank, and that of a Fungoid Frog (Hydrophylax malabaricus) as the outgroup.

Table 1. Pairwise distances (\%) between Bicolored Frogs (Clinotarsus curtipes), related taxa, and the Fungoid Frog (Hydrophylax malabaricus) (outgroup).

$\begin{array}{lllllll}1 & 2 & 3 & 4 & 5 & 6 & 7\end{array}$

\begin{tabular}{|c|c|c|c|c|c|c|c|c|}
\hline 1 & KM069013.1 C. curtipes & & & & & & & \\
\hline 2 & MZ358104-CC1098 & 0.0043 & & & & & & \\
\hline 3 & MZ358102-NCBS-AQ-223 & 0.0022 & 0.0066 & & & & & \\
\hline 4 & MZ358101-NCBS-AQ-224 & 0.0022 & 0.0066 & 0.0000 & & & & \\
\hline 5 & KR869788.1 C. alticola & 0.1276 & 0.1276 & 0.1276 & 0.1276 & & & \\
\hline 6 & KR869787.1 C. alticola & 0.1272 & 0.1272 & 0.1272 & 0.1272 & 0.0044 & & \\
\hline 7 & MG909603.1 C. penelope & 0.1388 & 0.1388 & 0.1388 & 0.1388 & 0.0562 & 0.0561 & \\
\hline 8 & KP826817.1 H. malabaricus & 0.2123 & 0.2163 & 0.2163 & 0.2163 & 0.1825 & 0.1858 & 0.1886 \\
\hline
\end{tabular}

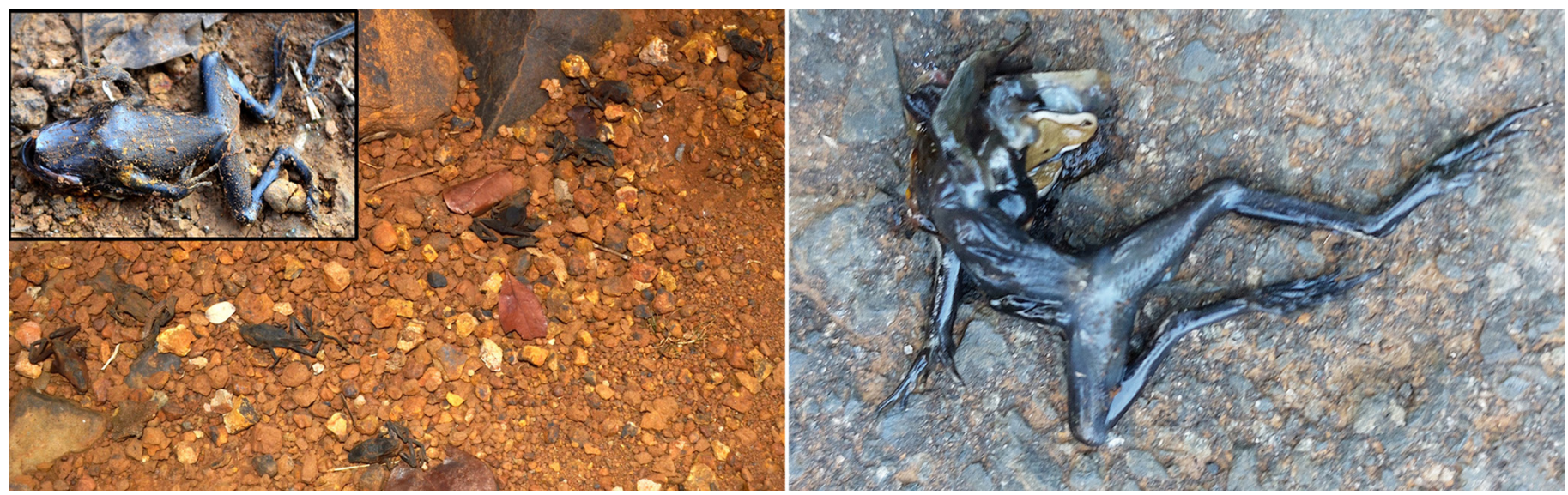

Fig. 4. Bicolored Frogs (Clinotarsus curtipes) dead on the forest floor, presumably victims of reduced forest cover and summer heat (left), and a road-killed individual (right). Photographs by Omkar V. Yadav. 
is essentially similar to that described for populations in the southern Western Ghats (Krishna and Krishna 2005). The genetic distance between individuals from the northern and southern limits (Kumily, Idukki District, Kerala) of the species' range was less than $0.7 \%$ (Table 1). Despite the discontinuity in the known distribution, the high genetic homogeneity between the sequences of individuals from opposite ends of the range suggests that populations might occur in intervening areas or that the species has only recently expanded its range in the Western Ghats. Habitat destruction, anthropogenic interference, climate change, and roadkills (Fig. 4) are major threats we observed during this study.

\section{Acknowledgements}

We thank the Maharashtra and Kerala Forest Departments for granting permission to conduct this study. Varad Giri, Akshay Khandekar, and Tejas Patil helped with the study, and Amol Patil, Omkar Gurav, and Pankaj Kamble assisted in the field.

\section{Literature Cited}

Biju, S.D., S.K. Dutta, and R. Inger. 2004. Clinotarsus curtipes. The IUCN Red List of Threatened Species 2004: e.T58583A11789937. https://dx.doi. org/10.2305/IUCN.UK.2004.RLTS.T58583A11789937.en.

Daniels, J.C. 2002. The Book of Indian Reptiles and Amphibians. Bombay Natural History Society and Oxford University Press, Mumbai, India.

Felsenstein, J. 1985. Confidence limits on phylogenies: an approach using the bootstrap. Evolution 39: 783-791.

Frost D.R. 2021. Amphibian Species of the World: An Online Reference. Version 6.1. American Museum of Natural History, New York, New York, USA. https:// amphibiansoftheworld.amnh.org/index.php. https://doi.org/10.5531/db.vz.0001.

Gopalan, S.V., S.U. Kumar, K.S. Kumar, and S. George. 2014. Genetic diversity of an endangered bush frog Pseudophilautus wynaadensis (Jerdon, 1854 "1853") from the south of Palghat gap, Western Ghats, India. Mitochondrial DNA 27: 3846-3851. https://doi.org/10.3109/19401736.2014.958673.

Krishna, S.N. and S.B. Krishna. 2005. Breeding population size of an endemic litter frog, Clinotarsus curtipes, in the Western Ghats, south India. Herpetological Review 36: 21-23.

Tamura, K., D.P. Peterson, N.G. Stecher, M. Nei, and S. Kumar. 2011. MEGA5: molecular evolutionary genetics analysis using maximum likelihood, evolutionary distance, and maximum parsimony methods. Molecular Biology and Evolution 28: 2731-2739. https://doi.org/10.1093/molbev/msr121.

Wemmer, C. and K.A. Nanjappa. 1996. "Battalion movement" in recently metamorphosed bicoloured frogs (Rana curtipes). Journal of the Bombay Natural History Society 93: 302-303. 